\title{
Potensi Perolehan Energi Listrik dalam Proses Pengolahan Limbah Tahu Melalui Microbial Fuel Cell (MFC)
}

\author{
Ayu Diah Syafaati ${ }^{*}$, Diana Rahayuning Wulan², Irwan Nugraha ${ }^{3}$ \\ ${ }^{1,3}$ Jurusan Kimia, Fakultas Sains dan Teknologi, UIN Sunan Kalijaga Yogyakarta \\ ${ }^{2}$ Bidang Teknologi Lingkungan, Pusat Penelitian Kimia, Lembaga Ilmu Pengetahuan Indonesia (LIPI) Bandung \\ *ayudiahsyafaati17@gmail.com
}

\begin{abstract}
ABSTRAK
Kebutuhan energi di Indonesia yang semakin meningkat, mendorong dikembangkannya berbagai penelitian berbasis teknologi terbarukan yang efisien dan ramah lingkungan. Salah satu teknologi alternatif yang dikembangkan adalah Microbial Fuel Cell (MFC). Microbial Fuel Cell (MFC) bekerja dengan memanfaatkan mikroorganisme untuk mendegradasi senyawa organik sehingga dapat menghasilkan energi listrik. Beberapa penelitian MFC telah dilakukan pada Single MFC. Pada penelitian ini dilakukan pengembangan untuk mengetahui pengaruh pengolahan limbah secara Stack Microbial Fuel Cell (MFC) terhadap kuat arus yang diproduksi. Sistem ini menggunakan elektroda karbon brush, Proton Exchange Membran (PEM) sebagai penukar kation, limbah cair tahu sebagai sumber substrat, dan isolat bakteri asli limbah cair tahu sebagai pendegradasi, sehingga diketahui kemampuan dalam sistem tersebut untuk menghasilkan energi listrik sekaligus menurunkan nilai Chemical Oxygen Demand (COD). Nilai Optical Density (OD) diukur untuk mengetahui aktivitas metabolisme bakteri, dengan panjang gelombang $570 \mathrm{~nm}$. Hasil penelitian menunjukkan bahwa proses Microbial Fuel Cell (MFC) yang berlangsung selama 72 jam menghasilkan potensi kuat arus listrik sebesar 0,96 mA pada Stack MFC dan Blanko sebesar 0,43 mA. Dibandingkan dengan Blanko Single Chamber, perolehan kuat arus listrik Stack MFC lebih besar. Sistem ini juga menurunkan nilai Chemical Oxygen Demand (COD) pada range $28-38 \%$.
\end{abstract}

Kata Kunci: Chemical Oxygen Demand; Microbial Fuel Cell; Stack MFC; Limbah Tahu,; Kuat Arus

\begin{abstract}
The need of energy in Indonesia was increasing and encouraging to develope some efficient renewable technology and environmental friendly researches. One of the alternative energy that can be used is Microbial Fuel Cell (MFC). Microbial Fuel Cell (MFC) works by using microorganisms to degrade organic compounds that can generate electrical energy. Several studies have been conducted on Single Chamber MFC. In this study, conducted to determine the effect of wastewater treatment through Stack Microbial Fuel Cell (MFC) on current producing. The system used carbon brush electrode, Proton Exchange Membrane (PEM) as cation exchanger, tofu liquid waste as source of substrate, and bacterial isolated tofu liquid waste as degrading organic substrate, that has known in system's ability to generate electrical energy as well as reduce COD value. Optical Density (OD) value was measured to determine the metabolic activity of bacteria, with wavelength $570 \mathrm{~nm}$. The research showed that Microbial Fuel Cell (MFC) that lasted for 72 hours resulted potential of electrical current $0.96 \mathrm{~mA}$ at Stack MFC and Blank 0,43 mA. The acquisition of electric current Stack MFC was greater than Blank Single Chamber. In addition, it also decreased Chemical Oxygen Demand (COD) value in the range of $28-38 \%$.
\end{abstract}


Keywords: Chemical Oxygen Demand; Current; Microbial Fuel Cell; Stack MFC; Tofu liquid waste

\section{PENDAHULUAN}

Penggunaan bahan bakar berbasis hidrogen telah banyak digunakan untuk berbagai keperluan pembangkit energi. Salah satunya adalah digunakan untuk membangkitkan listrik melalui fuel cell. Fuel Cell merupakan energi alternatif ramah lingkungan yang telah banyak dikembangkan. Fuel Cell bersifat ramah lingkungan karena tidak menghasilkan pencemaran, bahkan dapat digunakan untuk mengatasi masalah lingkungan dengan cara mendaur ulang limbah menjadi sumber energi. Fuel cell tersusun atas dua unit dasar, yaitu anoda dan katoda. Anoda berperan sebagai tempat terjadinya pemecahan hidrogen menjadi proton dan elektron. Katoda berperan sebagai tempat terjadinya reaksi penggabungan proton, elektron, dan oksigen untuk membentuk air (Shukla et al.,2004). Fuel Cell menghasilkan energi dalam bentuk energi listrik dengan cara memproduksi dan mengendalikan arus elektron. Fuel Cell konvensional memperoleh elektron dengan melepaskan atom hidrogen. Untuk menghasilkan hidrogen bebas maka dibutuhkan katalis yang ditempatkan dalam ruang anoda (Nasruddin, 2009). Katalis tersebut dapat berasal dari sel hidup seperti mikroba. Fuel Cell jenis ini disebut dengan Microbial Fuel Cell (MFC).

Microbial Fuel Cell (MFC) menjadi salah satu teknologi alternatif yang dipilih dikarenakan sifatnya yang ramah lingkungan dan mampu mengurangi dampak pencemaran lingkungan yang dihasilkan limbah organik, serta MFC berpotensial menghasilkan energi listrik. Microbial Fuel Cell (MFC) memanfaatkan materi organik yang digunakan oleh mikroba sebagai sumber energi dalam melakukan aktivitas metabolisme. Microbial Fuel Cell (MFC) bekerja melalui aksi bakteri yang dapat mengantarkan elektron-elektron ke anoda. Elektron mengalir dari anoda melalui sebuah kawat ke katoda yang menghasilkan arus listrik (Rabaey et al., 2005). Selain ramah lingkungan, Microbial Fuel Cell (MFC) memiliki kelebihan, dimana energi listrik yang dihasilkan berasal dari pemanfaatan limbah organik. Salah satu limbah organik yang dapat dimanfaatkan adalah limbah cair tahu.

Limbah tahu berasal dari Industri tahu, dimana menghasilkan dua macam limbah tahu, yaitu limbah padat dan limbah cair. Limbah padat berupa ampas tahu yang diperoleh pada saat ekstraksi susu kedelai (penyaringan), sedangkan limbah cair dihasilkan setelah koagulasi protein susu kedelai dan pada saat proses pengepresan atau pencetakan tahu. Limbah cair tahu merupakan salah satu limbah yang banyak menimbulkan permasalahan lingkungan karena kandungan bahan organiknya yang tinggi serta mudah membusuk sehingga menghasilkan bau yang tidak sedap. Kandungan bahan organik dalam limbah cair tahu cukup tinggi, begitupun dengan kadar COD dan BOD-nya (Subekti, 2011). Kadar BOD yang dihasilkan sekitar 6.000-8.000 mg/L dan kadar COD-nya sebesar 8.000-11.400 $\mathrm{mg} / \mathrm{L}$, sehingga limbah cair tahu yang dihasilkan oleh industri tahu mempunyai tingkat pencemaran lingkungan yang cukup tinggi (Hery, 1993). Selain itu belum maksimalnya upaya penanganan limbah cair tahu pada industri-industri tahu menyebabkan terjadinya pencemaran lingkungan. Untuk mengurangi dampak yang ditimbulkan, maka dilakukan upaya pemanfaatan limbah cair tahu sebagai substrat pada sistem Microbial Fuel Cell (MFC).

Sistem Microbial Fuel Cell dalam perkembangannya memiliki berbagai tipe sesuai dengan aplikasinya. Berdasarkan desain kompartemennya terdapat tiga jenis 
MFC, yaitu Single Chamber MFC, DualChamber MFC, dan Stack MFC. Single Chamber merupakan jenis MFC yang hanya memiliki satu ruang, sementara Dual-Chamber memiliki dua ruang yang dipisahkan membran penukar kation atau jembatan garam. Serta Stack MFC merupakan rangkaian dari beberapa unit MFC baik dual chamber maupun single chamber yang dirangkai seri atau paralel dengan tujuan meningkatkan kapasitas daya yang bisa diproduksi.

Kebutuhan Oksigen Kimia atau Chemical Oxygen Demand (COD) digunakan untuk mengukur kandungan oksigen yang setara dengan bahan kimia untuk mengoksidasi kandungan bahan organik dari limbah. Semakin tinggi kandungan oksigen setara dengan jumlah limbah yang ada, semakin tinggi oksigen COD dan semakin tinggi potensi pencemaran tersebut. Dalam hal ini bahan buangan organik akan dioksidasi oleh kalium dikromat $\left(\mathrm{K}_{2} \mathrm{Cr}_{2} \mathrm{O}_{7}\right)$ yang digunakan sebagai sumber oksigen. Reaksi tersebut perlu pemanasan dan juga penambahan katalisator perak sulfat $\left(\mathrm{AgSO}_{4}\right)$ untuk mempercepat reaksi (Sincero, 2002). Pengukuran COD didasarkan pada kenyataan bahwa hampir semua bahan organik dapat dioksidasi menjadi karbondioksida dan air dengan bantuan oksidator kuat (kalium dikromat) dalam suasana asam. Dengan menggunakan kalium dikromat sebagai oksidator, diperkirakan $95 \%-100 \%$ bahan organik dapat teroksidasi (APHA, 1992).

Novitasari (2011) menganalisis potensi bakteri Lactobacillus bulgaricus sebagai penghasil listrik dalam sistem MFC. Diperoleh bahwa potensi bakteri dalam menghasilkan energi listrik maksimum sebesar 0,302 mA dan $208 \mathrm{mV}$ selama waktu operasi 100 jam. Heryani (2012) telah melakukan penelitian dengan menggunakan limbah cair tahu dengan sistem dual chamber MFC. Diperoleh penurunan kadar COD hingga 49,33\%, sementara kuat arus diperoleh sebesar 7 7,9 mA.

Pada penelitian ini dilakukan pengembangan untuk mengetahui pengaruh pengolahan limbah dengan Microbial Fuel Cell (MFC) terhadap kuat arus yang diproduksi menggunakan isolat bakteri asli pada limbah serta penurunan nilai Chemical Oxygen Demand (COD) yang diperoleh setelah sistem dilakukan.

\section{METODOLOGI PENELITIAN}

\section{Alat dan Bahan}

Alat-alat yang digunakan pada penelitian antara lain: reaktor $\mathrm{MFC}, \mathrm{pH}$ meter, botol schott, hot plate, inkubator, furnace, oven, ultrasonic cleaner batch, autoklaf, alat sentrifugasi, kertas saring, cawan porselin, desikator, timbangan analitik, dan alat-alat gelas. Reaktor MFC terdiri dari bejana kaca, elektroda, dan kabel.

Elektroda yang digunakan pada penelitian ini merupakan elektroda karbon Sheet $8 \times 10 \mathrm{~cm}^{2}$. Elektroda terlebih dahulu diaktivasi untuk menghilangkan pengotor. Elektroda karbon yang telah disiapkan, direndam dalam asam sulfat $\left(\mathrm{H}_{2} \mathrm{SO}_{4}\right) 0,1 \mathrm{~N}$ dan asam nitrat $\left(\mathrm{HNO}_{3}\right) \quad 0,1 \mathrm{~N}$ selama 3 jam di dalam Ultrasonic Cleaner Batch dengan rasio volume 3:1. Setelah itu rendam dalam etanol hingga $\mathrm{pH}$ konstan dan dikeringkan di dalam oven pada suhu $100{ }^{\circ} \mathrm{C}$ selama 1 jam. Kemudian disimpan di tempat kering hingga pemakaian.

\section{Prosedur}

\section{Preparasi Alat dan Bahan}

Substrat yang digunakan merupakan limbah cair tahu. Limbah cair tahu disterilisasi ke dalam Autoklaf pada suhu $121{ }^{\circ} \mathrm{C}$ selama 15 menit. Dan elektroda yang digunakan merupakan elektroda karbon Sheet $8 \times 10 \mathrm{~cm}^{2}$. Elektroda terlebih dahulu diaktivasi untuk menghilangkan pengotor. Elektroda karbon yang telah disiapkan, direndam dalam asam sulfat 
$\left(\mathrm{H}_{2} \mathrm{SO}_{4}\right)$ 0,1 $\mathrm{N}$ dan asam nitrat $\left(\mathrm{HNO}_{3}\right) 0,1$ $\mathrm{N}$ selama 3 jam di dalam Ultrasonic Cleaner Batch dengan rasio volume 3:1. Setelah itu rendam dalam etanol hingga $\mathrm{pH}$ konstan dan dikeringkan di dalam oven pada suhu $100{ }^{\circ} \mathrm{C}$ selama $1 \mathrm{jam}$.

Proton Exchange Membran (PEM) yang digunakan adalah membran Nafion. Sebelum diaplikasikan terlebih dahulu dilakukan pre-treatment dengan cara dididihkan dalam asam peroksida $\left(\mathrm{H}_{2} \mathrm{O}_{2}\right)$ $30 \%$ selama 1 jam. Kemudian direbus dengan akuades selama 1 jam, lalu dididihkan dengan asam sulfat $\left(\mathrm{H}_{2} \mathrm{SO}_{4}\right) 0,5$ M selama 1 jam. Terakhir dibilas dan dididihkan kembali dengan akuades selama 1 jam (Eaktasang et al., 2012). Membran disimpan didalam akuades hingga saat akan digunakan. Sebelum diaplikasikan, membran dikeringkan dengan cara diangin-anginkan (Novitasari, 2011).

\section{Tahap Isolat Bakteri}

Tahap isolasi bakteri dilakukan dengan menyiapkan sampel limbah cair tahu, Dilution Water $(D W)$, dan media agar. Digunakan sampel limbah tahu, serta DW dan media agar sebagai blanko. Metode yang digunakan adalah pengenceran bertingkat hingga $10^{-6}$ dan spread plate. Semua metode kerja menggunakan prosedur aseptis. Setelah semua sampel telah selesai pada tahap dimasukkan ke dalam cawan petri, kemudian diinkubasi di dalam inkubator pada suhu $30^{\circ} \mathrm{C}$ selama 18 jam, dan dilihat koloni bakteri yang tumbuh. Setelah terbentuk adanya koloni bakteri, diisolasi kembali dengan memasukkan 1 ose isolat yang berasal dari cawan petri ke agar NA miring untuk mendapatkan isolat bakteri asli dari limbah cair tahu.

\section{Aklimatisasi Bakteri}

Aklimatisasi merupakan proses adaptasi bakteri pendegradasi dengan substrat (limbah tahu). Proses ini dilakukan menggunakan sebuah reaktor single chamber dengan 2 tahap variasi media dan limbah, yaitu $70 \%$ media dan $30 \%$ limbah serta $40 \%$ media dan $60 \%$ limbah. Dilakukan selama waktu operasi 72 jam, dan diukur nilai OD dan $\mathrm{pH}$.

\section{Running MFC}

Running MFC dilakukan dengan penyusunan reaktor yang akan digunakan dalam sistem Stack Microbial Fuel Cell. Stack MFC terdiri dari tiga buah reaktor single chamber (Reaktor A; SCMFC_A, Reaktor B; SCMFC_B, dan Reaktor C; SCMFC_C) disusun secara paralel dan digunakan sebuah reaktor single chamber yang berfungsi sebagai blanko. Didalam ruang anoda dimasukkan substrat berupa limbah cair tahu yang telah disterilisasi dan inokulum bakteri. Kemudian elektroda pada ruang anoda dan katoda dihubungkan dengan kabel multimeter. Pada blanko, kabel dari ruang katoda dihubungkan dengan muatan negatif pada multimeter, sementara kabel dari ruang anoda dihubungkan dengan muatan positif pada multimeter. Sedangkan pada Stack MFC rangkaian paralel, masing-masing kabel antar ruang anoda pada ketiga reaktor saling dihubungkan, begitu pula kabel antar ruang katoda, sehingga rangkaian yang terbentuk saling berhubungan. Diukur kuat arus serta OD dan $\mathrm{pH}$ pada sistem setiap 6 jam sekali selama waktu operasi 72 jam. Dilakukan juga pengukuran parameter COD setiap 12 jam sekali. Pada sistem Stack MFC ini juga dilakukan pengadukan selama sistem berlangsung.

\section{Analisis Chemical Oxygen Demand (COD) (SNI 6989.73:2009)}

ini mengukuran COD pada penelitian 6989.73:2009, Air dan air limbah Bagian 73: Cara uji kebutuhan oksigen kimiawi (Chemical Oxygen Demand/COD) dengan refluks tertutup secara titrimetri. Pengukuran Chemical Oxygen Demand (COD) dilakukan setiap 12 jam sekali dimulai dari jam ke-0 hingga jam ke-72. Sebanyak $5 \mathrm{~mL}$ sampel dari hasil pengambilan sampling COD setiap 12 jam diawetkan dengan larutan Asam Sulfat $\left(\mathrm{H}_{2} \mathrm{SO}_{4}\right) 1 \mathrm{~mL}$. Kemudian sampel yang 
telah ditambahkan asam sulfat dilakukan sentrifugasi menggunakan alat sentrifuge selama 15 menit pada $7000 \mathrm{rpm}$. Terjadi pemisahan antara sampel terlarut dengan analit. Diambil $2 \mathrm{~mL}$ sampel terlarut dan diencerkan dengan akuades hingga volume $50 \mathrm{~mL}$. Dari hasil pengenceran diambil 2 $\mathrm{mL}$ larutan sampel dan dimasukkan ke dalam tabung COD. Ditambahkan $2 \mathrm{~mL}$ larutan $\mathrm{K}_{2} \mathrm{Cr}_{2} \mathrm{O}_{7} 0,05 \mathrm{~N}, 0,5 \mathrm{~mL}$ larutan $\mathrm{Ag}_{2} \mathrm{SO}_{4}$, dan $2 \mathrm{~mL} \mathrm{H}_{2} \mathrm{SO}_{4}$. Tabung COD ditutup rapat-rapat jangan sampai sedikit terbuka. Larutan tersebut didestruksi menggunakan pemanas COD pada suhu $150{ }^{\circ} \mathrm{C}$ selama \pm 2 jam. Setelah dipanaskan larutan didinginkan pada suhu kamar. Kemudian larutan dipindahkan ke dalam erlenmeyer hingga benar-benar bersih. Larutan tersebut dititrasi dengan larutan baku FAS yang telah diketahui konsentrasinya hingga berubah warna menjadi merah bata atau merah cokelat.

\section{HASIL DAN PEMBAHASAN}

Hasil

\section{Karakteristik Limbah Cair Tahu}

Tabel 1. Karakteristik Limbah Cair Industri Tahu saat fresh dan pasca sterilisasi

\begin{tabular}{|c|c|c|c|c|}
\hline \multirow[b]{2}{*}{ Parameter } & \multirow[b]{2}{*}{$\begin{array}{c}\text { Satua } \\
\mathbf{n}\end{array}$} & \multicolumn{2}{|c|}{ Nilai } & \multirow[b]{2}{*}{$\begin{array}{c}\text { Baku } \\
\text { Mutu }\end{array}$} \\
\hline & & Fresh & $\begin{array}{c}\text { Pasca } \\
\text { Sterilis } \\
\text { asi }\end{array}$ & \\
\hline $\mathrm{pH}$ & - & 6,78 & 5,46 & $6-9$ \\
\hline $\begin{array}{c}\text { Chemical } \\
\text { Oxigen } \\
\text { Demand }\end{array}$ & $\mathrm{Mg} / \mathrm{L}$ & 4191,6 & 2994 & 300 \\
\hline Warna & - & $\begin{array}{c}\text { Kuning } \\
\text { Keputi } \\
\text { han }\end{array}$ & $\begin{array}{c}\text { Kuning } \\
\text { Kecokla } \\
\text { tan }\end{array}$ & - \\
\hline $\begin{array}{l}\text { Sumber: } \\
\text { Lingkungan }\end{array}$ & Bak & $\begin{array}{l}\text { Mutu } \\
\text { Tahun }\end{array}$ & $\begin{array}{l}\text { PerMen } \\
14 \text { Lamp }\end{array}$ & Negara \\
\hline
\end{tabular}

\section{Tahap Aklimatisasi}

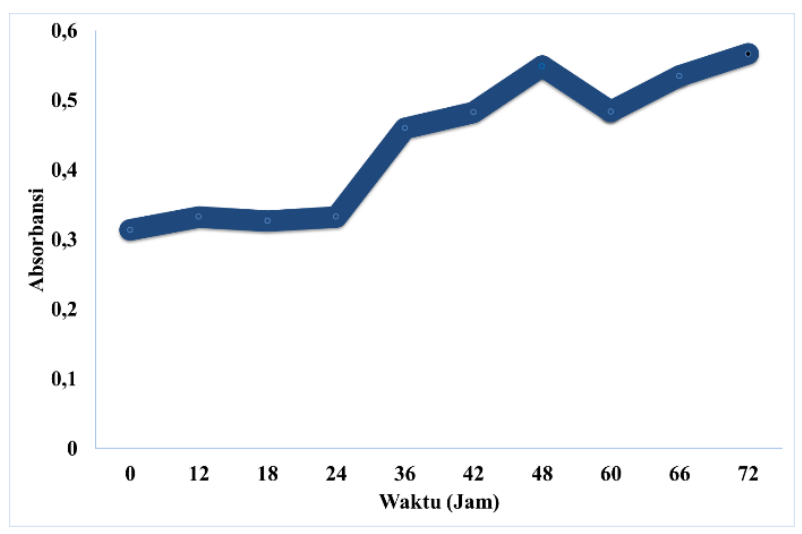

Gambar 1. Nilai Optical Density (OD) Tahap Aklimatisasi 1

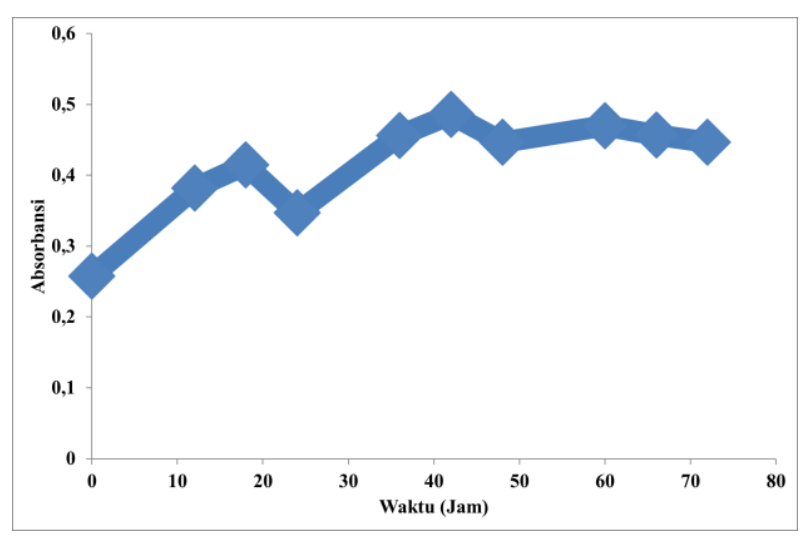

Gambar 2. Nilai Optical Density (OD) Tahap Aklimatisasi 2

Tahap Running MFC

Pengukuran Energi Listrik

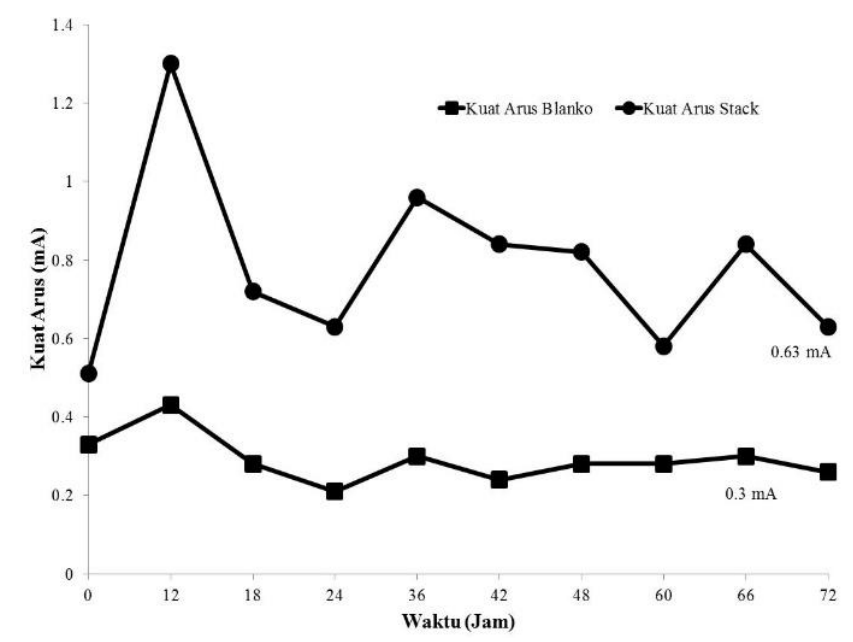

Gambar 3. Pengaruh waktu terhadap kuat arus yang dihasilkan Stack MFC dan Blanko 


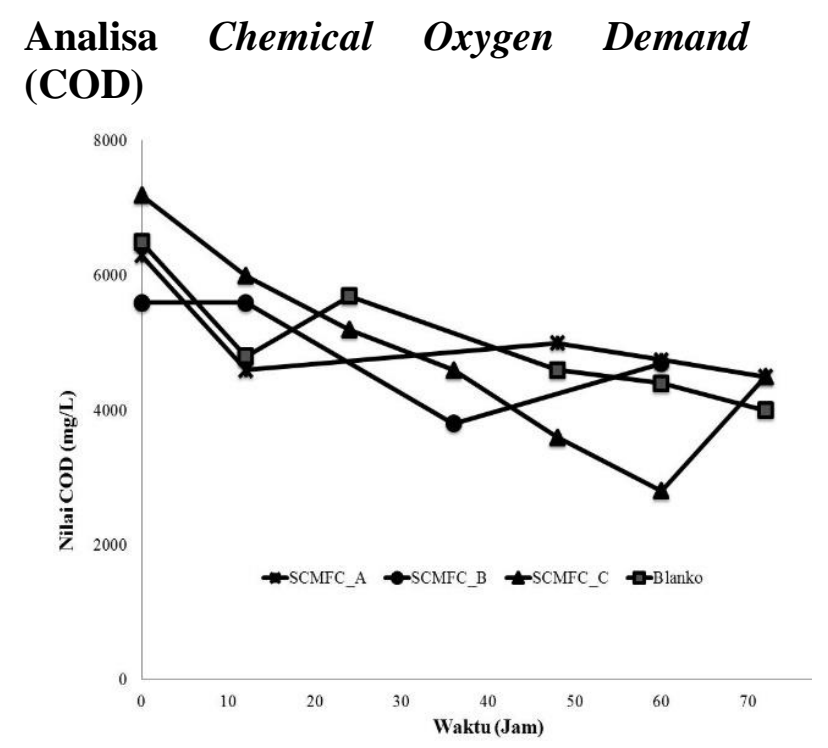

Gambar 4. Pengaruh waktu terhadap nilai COD yang dihasilkan Stack MFC (Stack MFC A, B, dan C) serta Blanko

\section{Pembahasan \\ Karakteristik Limbah Cair Tahu}

Limbah cair tahu yang telah disterilisasi kemudian akan digunakan sebagai substrat pada sistem MFC. Dari hasil analisis pendahuluan sebagaimana Tabel 1 dapat diketahui pada limbah cair tahu fresh (baru diambil dari industri tahu) diperoleh nilai $\mathrm{pH}$ awal berada pada $\mathrm{pH}$ 6,78 dan setelah disterilisasi berada pada $\mathrm{pH} 5,46$, hal tersebut merupakan kondisi optimum bagi mikroba untuk melakukan proses biodegradasi dan bioflokulasi limbah. Selain itu, nilai $\mathrm{pH}$ awal pada limbah cair tahu tersebut juga berada pada rentang baku mutu yang telah ditetapkan. Sementara itu, jika dilihat karakteristik limbah cair tahu pada Herlambang (2002), besar nilai COD yang diperoleh dari kedua jenis limbah cenderung lebih kecil, yaitu sebesar 2994 dan 4191,6 mg/L. Diasumsikan bahwa kandungan bahan organik pada limbah cair tahu belum terlalu besar, dikarenakan limbah yang digunakan merupakan limbah cair tahu yang diambil bagian atasnya setelah terlebih dahulu dilakukan proses pengendapan terhadap limbah cair tahu.

\section{Desain Reaktor Stack Microbial Fuel Cell (MFC)}

Stack Microbial Fuel Cell (MFC) merupakan jenis MFC yang didasarkan pada desain kompartemennya. Stack MFC adalah jenis MFC yang menggunakan satu atau lebih reaktor yang disusun secara paralel maupun seri, yang bertujuan untuk meningkatkan perolehan tegangan dan kuat arus listrik. Pada penelitian ini menggunakan MFC dengan jenis sistem Stack MFC yang dirangkai secara paralel dengan satu reaktor (Single Chamber). Terdapat tiga buah reaktor Single Chamber yang disusun secara paralel (Gambar 6), serta sebuah reaktor Single Chamber sebagai blanko (Gambar 5).

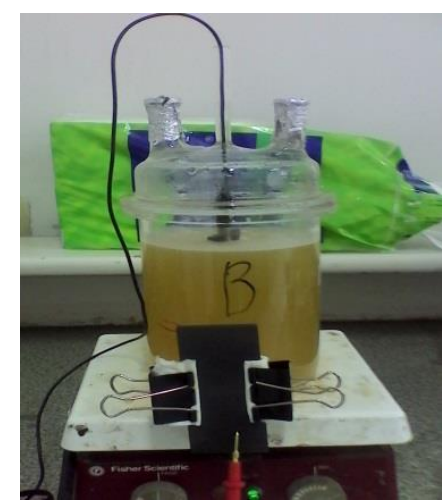

Gambar 5. Reaktor Blanko MFC

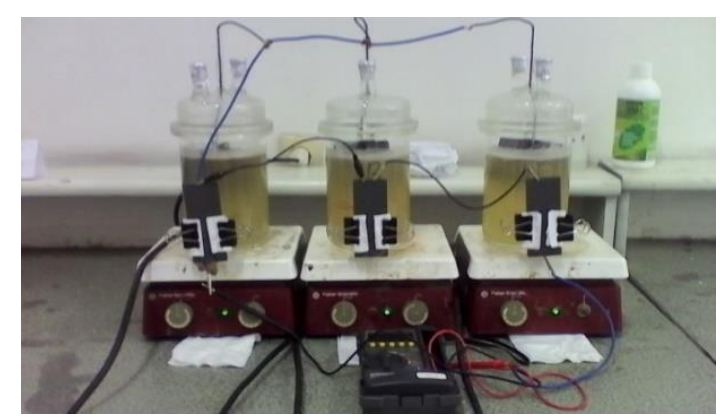

Gambar 6. Reaktor Stack Microbial Fuel Cell (MFC) (Reaktor A, B, dan C)

Reaktor yang digunakan memiliki volume $1000 \mathrm{~mL}$, terdiri dari $900 \mathrm{~mL}$ limbah dan $100 \mathrm{~mL}$ inokulum bakteri. Sistem ini menggunakan elektroda karbon brush pada bagian anoda dan katodanya, yang dipisahkan dengan sebuah membran 
yaitu Proton Exchange Membrane (Membran Nafion) yang biasa digunakan dalam penelitian MFC sebagai membran penukar proton. PEM ini digunakan untuk memisahkan kompartemen anoda dan katoda secara fisik dalam desain MFC untuk memberikan jalur bagi $\mathrm{H}^{+}$dari kompartemen anoda menuju katoda sementara elektron tidak dapat berdifusi melalui membran ini. Sebelum digunakan, PEM ditreatment terlebih dahulu, hal tersebut dilakukan untuk membersihkan pori-pori membran dari kontaminan sehingga tidak mengganggu proses perpindahan masa yang berlangsung selama proses MFC (Chae et al., 2008). Kabel tembaga digunakan untuk menghubungkan elektroda ke multimeter. Kemudian setelah instrumen lengkap dipasang, eksperimen MFC dijalankan dengan menutup anoda dengan tutup reaktor untuk menjaga kondisi lingkungan anaerobik. Pada sistem MFC ini dilakukan pengadukan setiap waktu yang bertujuan untuk mengurangi terjadinya pengendapan pada sistem MFC.

\section{Tahap Aklimatisasi}

Sistem MFC menggunakan mikroorganisme dalam mendegradasi material organik. Pada penelitian ini digunakan mikroorganisme yang berasal dari bakteri limbah cair tahu yang telah diisolasi. Setelah diperoleh isolat bakteri limbah cair tahu, dilakukan aklimatisasi. Tahap aklimatisasi merupakan tahap pengadaptasian bakteri terhadap substrat. Dilakukan 2 kali tahap aklimatisasi. Tahap aklimatisasi pertama dengan persentase antara media dan limbah cair tahu sebesar $70 \%$ dan 30\%. Sementara persentase antara media dan limbah pada tahap aklimatisasi kedua sebesar $40 \%$ dan $60 \%$. Setiap tahap berlangsung selama waktu operasi 72 jam dengan dilakukan pengukuran OD. Aktivitas bakteri pada tahap aklimatisasi pertama dapat dilihat melalui kurva pertumbuhan yang ditentukan dengan mengukur turbiditas melalui nilai optical density (OD) pada panjang gelombang $560 \mathrm{~nm}$ menggunakan spektrofotometer UV-Vis.

Gambar 1 menunjukkan bahwa fase lag terjadi pada jam ke-0 sampai jam ke24 , kemudian memasuki fase eksponensial pada jam ke-24 sampai jam ke-72 tanpa menunjukkan fase kematian. Pada fase eksponensial, bakteri secara aktif memproduksi elektron melalui proses metabolisme dengan memanfaatkan nutrien yang tersedia. Selain itu bakteri juga menghasilkan metabolit primer berupa asam asetat. Proses yang berlangsung pada tahap aklimatisasi ini adalah proses anaerobik. Proses anaerobik terjadi karena aktivitas mikroorganisme yang dilakukan pada saat tidak terdapat oksigen bebas. Reaksi kimia pada proses anaerobik secara keseluruhan dapat disederhanakan sebagai berikut:

$$
\begin{aligned}
& \text { Zat Organik } \stackrel{\text { Mikroorganisme }}{\text { Anaerobik }} \\
& \mathrm{CH}_{4}+\mathrm{CO}_{2}+\mathrm{H}_{2}+\mathrm{N}_{2}+\mathrm{H}_{2} \mathrm{~S}
\end{aligned}
$$

Degradasi zat organik secara mikrobiologi dalam lingkungan anaerobik hanya dapat dilakukan oleh mikroorganisme yang dapat menggunakan molekul selain oksigen sebagai akseptor hidrogen. Dekomposisi anaerobik menghasilkan biogas yang terdiri atas gas methan $(50-70 \%), \mathrm{CO}_{2}(25-$ $40 \%$ ) dan sejumlah kecil $\mathrm{H}_{2} \mathrm{~S}$.

Ada tiga tahapan dasar yang termasuk dalam keseluruhan proses pengolahan limbah secara oksidasi anaerobik, yaitu: hidrolisis, fermentasi (yang juga dikenal dengan sebutan asidogenesis), dan metanogenesis (Metcalf and Eddy, 2003). Selama proses hidrolisis, bakteri merubah materi organik kompleks yang tidak larut, seperti selulosa, menjadi molekul-molekul yang dapat larut, seperti asam lemak, asam amino dan gula. Materi polimer komplek dihidrolisa menjadi monomer-monomer, contoh: selulosa menjadi gula atau alkohol. Molekulmolekul monomer ini dapat langsung dimanfaatkan oleh kelompok bakteri selanjutnya. Hidrolisis molekul kompleks 
dikatalisasi oleh enzim ekstra seluler seperti selulase, protease, dan lipase.

Proses fermentasi (asidogenesis), merubah gula, asam amino, dan asam lemak menjadi asam-asam organik (asam asetat, propionate, butirat, laktat, format) alkohol dan keton (etanol, methanol, gliserol dan aseton), asetat, $\mathrm{CO}_{2}$ dan $\mathrm{H}_{2}$ oleh bakteri asidogenik. Produk utama dari proses fermentasi ini adalah asetat. Proses metanogenesis dilaksanakan oleh suatu kelompok mikroorganisme yang dikenal sebagai bakteri metanogen. Bakteri metanogen yang berada di dalam proses anaerobik, yaitu bakteri acetogens, mampu menggunakan $\mathrm{CO}_{2}$ untuk mengoksidasi dan membentuk asam asetat, dimana asam asetat dikonversi menjadi metan. Akan tetapi, selama proses sistem MFC ini tidak sampai menghasilkan metana, dikarena reaksi yang terjadi tidak sempurna.

Tahap aklimatisasi ke-2 dilakukan menggunakan reaktor dengan elektroda karbon sheet. Aktivitas bakteri pada tahap aklimatisasi ke-2 dapat dilihat pada gambar 2. Optical Density (OD) pada chamber dengan elektroda karbon sheet menunjukkan fase lag pada jam ke-0 hingga 24, kemudian fase eksponensial pada jam ke-24 hingga 48, dan mengalami fase stasioner pada jam ke 48-60, serta mengalami fase kematian pada jam ke-60 hingga 72 ditunjukkan dengan adanya penurunan nilai absorbansi. Pada tahap aklimatisasi ini mengalami penurunan dan berada pada fase menuju kematian di waktu reaksi akhir.

\section{Tahap Running MFC \\ Pengukuran Energi Listrik}

Usaha peningkatan kinerja MFC dilakukan dalam rangka meningkatkan produksi energi listrik. Pada penelitian ini digunakan sistem Stack Microbial Fuel Cell rangkaian paralel dengan tiga buah reaktor single chamber dan sebuah single chamber sebagai blanko. Reaktor rangkaian paralel ini, diharapkan dapat menghasilkan peningkatan arus listrik yang dihasilkan. Kuat arus ditentukan menggunakan multimeter yang dihubungkan dengan kedua elektroda pada reaktor MFC. Anoda dihubungkan dengan kutub negatif pada multimeter dan katoda dihubungkan dengan kutub positif. Arus listrik dihasilkan akibat adanya pergerakan muatan-muatan dalam sistem, perbedaan potensial redoks pada anoda dan katoda dan perbedaan komposisi serta reaksi kimia dalam sistem MFC. Pengukuran kuat arus listrik pada sistem MFC ini dilakukan secara Open Circuit Voltage (OCV) yaitu, tanpa adanya penambahan hambatan eksternal seperti lampu atau resistor. Gambar 3 menunjukkan grafik perbandingan antara kuat arus pada blanko dan stack MFC. Diperoleh kuat arus listrik maksimum sistem MFC sebesar 0,43 mA pada blanko dan 1,3 mA pada Stack MFC, masing-masing terjadi pada jam ke-12. Berdasarkan perolehan tersebut menunjukkan bahwa sistem Stack MFC menghasilkan potensi arus listrik yang lebih besar daripada sistem single chamber, dalam hal ini dibandingkan dengan blankonya. Perolehan energi listrik baik dilihat dari arus listrik menunjukkan bahwa dengan menggunakan isolat bakteri asli dari limbah cair tahu pada proses pengolahan limbah cair tahu dengan sistem stack MFC, dapat menghasilkan energi listrik.

\section{Analisa Chemical Oxygen Demand (COD)}

Salah satu parameter pencemaran limbah cair yang dilakukan pada penelitian ini adalah Analisis COD. Analisis Chemical Oxygen Demand (COD) dilakukan sebagai parameter utama untuk menunjukkan bahan organik yang dapat dioksidasi oleh mikroorganisme. Dalam analisis ini bertujuan untuk mngetahui banyaknya kandungan oksigen yang dibutuhkan untuk menguraikan materi organik yang terdapat di dalam sampel limbah cair tahu secara kimia. Pengukuran COD dilakukan setiap 12 jam sekali selama waktu operasi 72 jam, dimulai dari jam ke-0. Sampel $C O D$ terlarut yang telah disentrifugasi ditambahkan dengan kalium dikromat untuk mengoksidasi materi 
organik pada sampel limbah. Ditambahkan asam sulfat pekat dengan katalisator perak sulfat dan dipanaskan selama 2,5 jam. Reaksi terhadap limbah cair adalah sebagai berikut :

$$
\begin{aligned}
& \mathrm{C}_{6} \mathrm{H}_{12} \mathrm{O}_{6}+4 \mathrm{Cr}_{2} \mathrm{O}_{7}^{2-}+32 \mathrm{H}^{+} \rightarrow \\
& 6 \mathrm{CO}_{2}+8 \mathrm{Cr}^{3+}+22 \mathrm{H}_{2} \mathrm{O}
\end{aligned}
$$

Setelah dipanaskan, kalium dikromat yang berlebih dititrasi dengan larutan fero amunium sulfat (FAS). Reaksi yang berlangsung adalah sebagai berikut :

$$
\begin{gathered}
\mathrm{Cr}_{2} \mathrm{O}^{2-}+14 \mathrm{H}^{+}+6 \mathrm{Fe}^{2+} \rightarrow 2 \mathrm{Cr}^{3+}+ \\
6 \mathrm{Fe}^{3+}+7 \mathrm{H}_{2} \mathrm{O}
\end{gathered}
$$

Kalium dikromat yang terpakai untuk oksidasi materi organik pada sampel dapat diketahui dan nilai $C O D$ dapat dihitung. Reaksi $C O D$ ini berjalan dengan lambat sehingga perlu adanya penambahan asam dan pemanasan serta katalisator untuk mempercepat proses reaksi. Penurunan kadar $C O D$ pada reaktor single chamber (blanko) dan stack MFC yang disusun secara paralel dapat dilihat pada gambar 4.

Nilai Chemical Oxygen Demand (COD) pada tahap Running MFC diperoleh adanya penurunan nilai COD, yaitu pada Blanko terjadi penurunan sebesar $38 \%$ (6489,6 mg/L - 3993,6 mg/L) dan pada Stack MFC terjadi penurunan sebesar $28 \%$ $(6289,92 \mathrm{mg} / \mathrm{L}-4492,8 \mathrm{mg} / \mathrm{L})$ pada Reaktor A, $19 \%$ (5591,04 mg/L - 4492,8 $\mathrm{mg} / \mathrm{L})$ pada Reaktor B, dan 37,5 \% $(7188,48 \mathrm{mg} / \mathrm{L}-4492,8 \mathrm{mg} / \mathrm{L})$ pada Reaktor C. Hal ini menunjukkan bahwa dengan menggunakan isolat bakteri asli pada pengolahan limbah cair tahu melalui sistem Stack Microbial Fuel Cell rangkaian paralel selama waktu operasi 72 jam dapat menurunkan nilai Chemical Oxygen Demand (COD) pada range $19-37,5 \%$. Menurut Liu et al., 2004, nilai COD pada air limbah setelah proses pengolahan menggunakan sistem MFC dapat berkurang hingga $80 \%$. Berdasarkan hasil yang diperoleh, ternyata penurunan COD belum berlangsung optimal. Ini dapat dimungkinkan karena kandungan senyawa organik pada limbah cair tahu belum berlangsung optimal.

\section{KESIMPULAN}

Berdasarkan penelitian yang dilakukan dapat disimpulkan bahwa penggunaan isolat bakteri limbah cair tahu terhadap perolehan maksimum energi listrik yang dihasilkan melalui Stack MFC dibandingkan dengan Blanko Single Chamber setelah proses MFC dilakukan adalah menghasilkan kuat arus listrik maksimum sebesar 0,43 $\mathrm{mA}$ pada blanko dan 1,3 mA pada Stack MFC, masingmasing terjadi pada jam ke-12.

Pengolahan limbah cair tahu melalui Stack Microbial Fuel Cell (MFC) yang dirangkai secara paralel dapat menurunkan kadar Chemical Oxygen Demand (COD) dengan range 19 - 37,5 \%, yaitu pada Blanko terjadi penurunan sebesar 38 \% (6489,6 mg/L - 3993,6 $\mathrm{mg} / \mathrm{L})$ dan pada Stack MFC terjadi penurunan sebesar 28\% (6289,92-4492,8 mg/L) pada Reaktor A, 19\% (5591,04 $4492,8 \mathrm{mg} / \mathrm{L})$ pada Reaktor B, dan $37,5 \%$ (7188,48 - 4492,8 mg/L) pada Reaktor C. Perbedaan penurunan nilai COD antara ketiga reaktor dimungkinkan dipengaruhi oleh aktivitas bakteri (OD) dalam masingmasing reaktor selama sistem berlangsung.

\section{UCAPAN TERIMA KASIH}

Penulis mengucapkan terima kasih kepada Ibu Diana Rahayuning Wulan dan Bapak Dani Permana atas arahan dan bimbingannya selama penelitian di Laboratorium Bidang Teknologi Lingkungan, LIPI Bandung.

\section{DAFTAR PUSTAKA}

APHA. 1992. Standard Methods for The Examination of Water and Wastewater 18th Edition. American Public Health Association. Washington.

Badan Standarisasi Nasional. 2009. SNI 6989.73:2009: Air dan air limbahBagian 73: Cara uji Kebutuhan Oksigen Kimiawi (Chemical 
Oxygen Demand/COD) dengan refluks tertutup secara titrimetri.

Chae, Kyu Jung. Choi, mijin. Ajayi, Folusho F. Park, Wooshin. Chang, In Seop. dan Kim, In S. 2008. Mass Transport through a Proton Exchange Membrane (Nafion) in Microbial Fuel Cells. Energy \& Fuels (22): 169-176.

Eaktasang, Numfon., Kim, Dooil., Lee, Jae Woo., Park, Ki Young., dan Kim, Han S. 2012. Enhancement of Electron Transfer by Electrochemical Treatment of Electrode in The Microbial Fuel Cell. International Conference of Chemical, Environmental Science and Engineering, Pattaya, Thailand.

Herlambang, A. 2002. Teknologi Pengolahan Limbah Cair Industri Tahu. Pusat Pengkajian dan Penerapan 79 Teknologi Lingkungan (BPPT) dan Badan Pengendalian Dampak Lingkungan Samarinda.

Hery, P. 1993. Abu Terbang dan Pemanfaatannya. Makalah Seminar Nasional Batubara Indonesia. UGM Yogyakarta.

Heryani, Hani. 2012. Penentuan Kuat Arus Listrik yang dihasilkan dari Sistem Microbial Fuel Cell dengan menggunakan Elektroda Tembaga pada Limbah Cair Industri Tahu. Skripsi. FMIPA Unjani, Cimahi.

Nasruddin, Harun. 2009. Pengembangan Sumber Energi Renewable Sel Bakar Mikroba Dalam Mengatasi Limbah Organik Selulotik. Surabaya: Universitas Negeri Surabaya.

Novitasari, Deni. 2011. Optimasi Kinerja Microbial Fuel Cell (MFC) Untuk Produksi Energi

Listrik
Menggunakan

Bakteri

Lactobacillus bulgaricus. Skripsi. Fakultas Teknik Kimia UI. Depok.

Permana, Dani., Haryadi, Hari R., Putra, Herlian Eriska., Juniati, Westy., Rachman, Saadah D., dan Ishmayana, Safri. 2013. Evaluasi Penggunaan Metilen Biru Sebagai Mediator Elektron pada Microbial Fuel Cell dengan Biokatalis Acetobacter aceti. Molekul, Vol. 8. No. 1 . Mei, 2013: 78-88.

Rabaey, Korneel and Willy Verstraete. 2005. Microbial Fuel Cells: Novel Biotechnology for Energy Generation. ELSEVIER Trends in Biotechnology Vol. 23 No.6 June 2005.

Shukla, A.K, Suresh, P., Berchmans, S., Rajendran, A. 2004. Biological Fuel Cell and Their Application. Current Science. 87(4): 455-468.

Sincero, A.P., and Sincero, G.A. 2012. Physical-Chemical Treatment of Water and Wastewater. IWA Publishing. London.

Subekti, Sri. 2011. Pengolahan Limbah Cair Tahu Menjadi Biogas Sebagai Bahan Bakar Alternatif. Prosiding Seminar Nasional Sains dan Teknologi ke-2 Tahun 2011 Fakultas Teknik Universitas Wahid Hasyim. Semarang. Hal: B61-B66. 